\title{
Preparation and Optical Characterization of Polymer Composites Reinforced by Natural Materials
}

\author{
Aseel S. Jasim \\ Department of Human Resources, Presidency of Al-Nahrain University, Baghdad-Iraq. \\ E-mail: aseelmap79@yahoo.com.
}

\begin{abstract}
Three groups of composite materials were prepared by using casting method from Unsaturated Polyester with volume fraction (70\%) reinforced by Rice Husks with volume fraction (30\%) (first group), the second group was prepared from Unsaturated Polyester with volume fraction (70\%) reinforced by Rice Husks with volume fraction (15\%) and by Palm Fibers with volume fraction (15\%) (hybird composite) and the third group consist also of Unsaturated Polyester with volume fraction $(70 \%)$ reinforced by Palm Fibers with volume fraction $(30 \%)$, the length of palm fibers was (2-3) $\mathrm{mm}$. Parameters such as absorbance (A), transmittance (T), reflectance $(\mathrm{R})$, refractive index $(\mathrm{n})$, extinction coefficient $(\mathrm{k})$, real $\left(\varepsilon_{\mathrm{r}}\right)$ and imaginary parts $\left(\varepsilon_{\mathrm{i}}\right)$ of dielectric constants, were studied in the spectral range (200-800) $\mathrm{nm}$. The results show that the absorbance increases with increasing the ratio of Palm Fibers while the transmittance decreases, the hybrid composite has the best values of reflectance and the higher values of extinction coefficient, Refractive index, real and imaginary parts of dielectric constants were for samples containing ratios of Palm Fibers and the lower values were for those contain Rice Husks only.
\end{abstract}

Keywords: Polymer Composite, hybrid composite, Rice Husk; date Palm Fibers and optical properties.

\section{Introduction}

Composites containing two materials with differences physical properties exhibit often new properties. The composites can provide improved characteristics not obtain able by any of the original components alone and are used in a wide variety of industrial products [1]. The term hybrid composite refers to the composite containing more than one type of fiber material as reinforcing filler [2]. Natural filler have many significant advantages such as the eco-friendly nature as well as their lightweight, low cost, low density, ability to reduce abrasion of machinery, and also non-toxicity [2-4], these properties have enhanced the attraction and interest of nature fiber reinforced composite.

Natural fibers have been proven alternative to synthetic fiber in transportation such as automobiles, railway coaches and aerospace. Other applications include military, building, packaging, consumer products and construction industries for ceiling paneling, partition boards $[5,6]$.

Polymer materials have been widely used in various fields such as industrial products [7].
The optical behavior of materials is important to determine it's usage in optoelectronic devices. Knowledge of optical constants of a material such as optical band gap, refractive index and extinction coefficient is quite essential to examine material's potential opto-electronic applications. Further, the optical properties may also be closely related to the material's atomic structure, electronic band structure and electrical properties [8].

The study of optical absorption and particularly the absorption edge is a useful method for the investigation of opticallyinduced transitions and for the provision of information about the band structure and energy gap in both crystalline and amorphous materials. The measurement of the optical absorption coefficient, particularly near the fundamental absorption edge, provide a standard method for investigation [9].

In this work, the effect of the variation of the ratio and the type of natural fillers (palm fibers, Rice husks) on some optical properties of polymer composite materials has been studied using UV-Visible spectroscopy. 


\section{Experimental Work}

1. Selection of Materials:

A. Matrix Material:

Unsaturated Polyester (UP) resin was used as matrix material, it is viscous liquid, hardening thermally, transparent liquid at room temperature, and Table (1) mentioned some properties of (UP) [10].

\section{Table (1)}

Some properties of Unsaturated polyester $(\boldsymbol{U P})$.

\begin{tabular}{||c||c||}
\hline Density $(\mathrm{gm} / \mathrm{cm} 3)$ & 1.4 \\
\hline \hline Service temp $\left({ }^{\circ} \mathrm{C}\right)$ & $70-80$ \\
\hline \hline Stability temp $\left({ }^{\circ} \mathrm{C}\right)$ & 220 \\
\hline
\end{tabular}

\section{B. Hardener:}

Methyl Ethyl Keton peroxide was used to convert unsaturated polyester from transparent liquid at room temperature to a solid state and to form a strong permanent band, the weight ratio between hardener and resin was $2 \mathrm{gm}$ of hardener per $100 \mathrm{gm}$ of the resin.

\section{Filler materials:}

1. Rice husk Fig.(1a) which is obtained from Al-Najaf rice farm (the first filler material).

2. The second filler material is date Palm fibers Fig.(1b) were collected locally from the date trees.

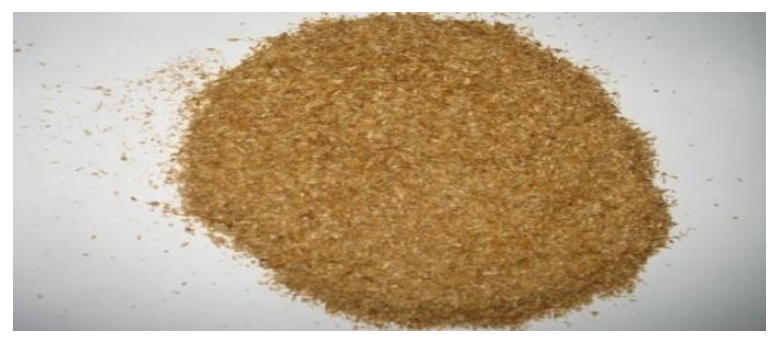

(a): Rice Husk Particles.

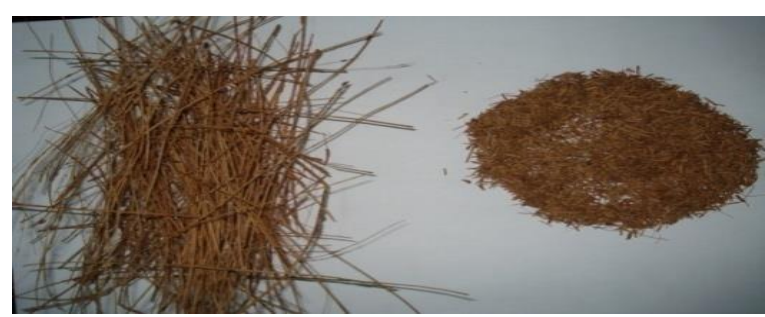

(b): Palm fibers.

Fig (1): (a) Rice Husk particles, (b) Palm Fibers.

\section{Composite preparation}

Hand lay-out technique was used to prepare the composite specimens by using a mould made from plate glass. Sheet of polyvinyl alcohol substance was fixed on the inner mould faces before casting to facilitate the releasing of casting polymer and having smooth faces. Palm fibers with length (2-3 $\mathrm{mm}$ ) and nearly with fixed diameter equal to (1) $\mathrm{mm}$, rice husk mixed with polyester resin by different volume fraction as mentioned in Table (2).

Table (2)

The composition of the prepared polymer composite materials.

\begin{tabular}{|c|c|c|c|}
\hline composition & 1 & 2 & 3 \\
\hline Vol.\% of polyester resin & 70 & 70 & 70 \\
\hline Vol.\% of rice husk & 30 & 0 & 15 \\
\hline Vol.\% of palm fibers & 0 & 30 & 15 \\
\hline
\end{tabular}

Fig.(2) shows the topography of the prepared composite materials determined by optical microscope.

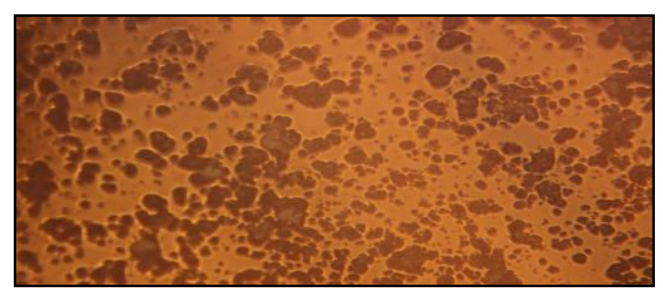

(a) $30 \% \mathrm{RH}, 70 \% \mathrm{UP}$.

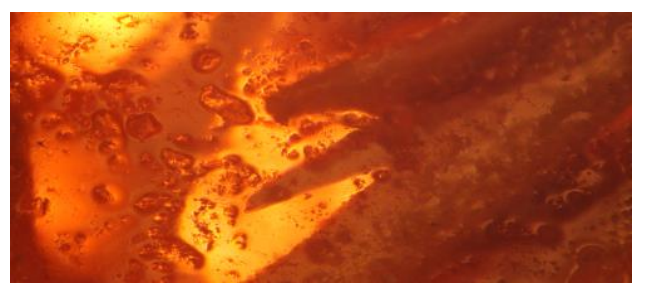

(b) $15 \% R H, 15 \% P F, 70 \% U P$.

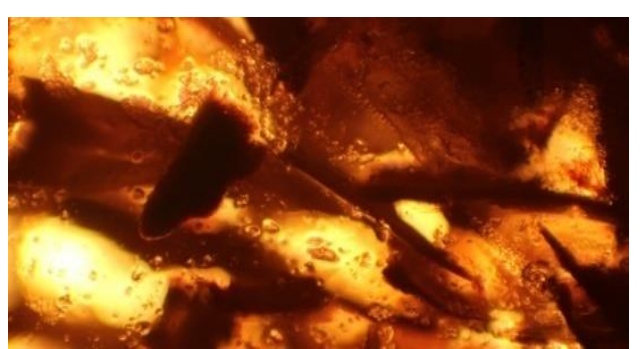

(c) $30 \% P F, 70 \% U P$.

Fig.(2): The topography of the three groups of prepared composites. 


\section{Optical measurements:}

The optical constants were calculated by using (Shimadzu 1601 PC) spectrophotometer in the wavelength range (200-800) $\mathrm{nm}$.

The spectroscopic behavior of materials is utilized to determine their optical constants (refractive index (n), extinction coefficient $(\mathrm{k})$, real and imaginary parts of dielectric constants $\left(\varepsilon_{\mathrm{r}}, \varepsilon_{\mathrm{i}}\right)$. Several methods were proposed to determine these optical constants; they involve measurements of absorbance (A), reflectance (R) and transmittance (T).

The absorbance (A) is defined as the logarithm of the ratio between absorbed light intensity (I) by material and the incident intensity of light $\left(\mathrm{I}_{\mathrm{o}}\right)$ of a sample, [7], [11]:

$\mathrm{A}=-\log \mathrm{T}=\log \left(\mathrm{I}_{\mathrm{o}} / \mathrm{I}\right)$

Where, $I_{0}$ is the intensity of incident light. I is the intensity of the absorbed light at distance (x).

The reflection $(\mathrm{R})$ can be obtained from the values of absorbance and transmission coefficient (T) [9], [12]:

$(\mathrm{R})=1-\mathrm{A}-\mathrm{T}$

The absorption coefficient $\alpha$ is related to the absorbance A based on the Lambert-Beer law [13]:

$\alpha=2.303 \mathrm{~A} / \mathrm{x}$

Where, $(\mathrm{x})$ is sample thickness in $(\mathrm{cm})$.

The thickness of the prepared samples was $(0.5) \mathrm{cm}$ and it was constant for all samples.

Dielectric constant is defined as the response of the material towards the incident electromagnetic field. The dielectric constant of compound $(\varepsilon)$ is divided into two parts real $\left(\varepsilon_{\mathrm{r}}\right)$ and imaginary $\left(\varepsilon_{\mathrm{i}}\right)$, the dielectric constant can be calculated using equation no.(4). [7],[14]:

$\varepsilon=\varepsilon_{\mathrm{r}}+\mathrm{i} \varepsilon_{\mathrm{i}}$

\section{Result and Discussion}

\section{Optical characterization}

Optical measurements of absorbance, transmittance and reflectance of the composite materials with different ratios of filler materials are shown in Figs. (3,4 and 5), these measurements were carried out in the range (200-800) nm.

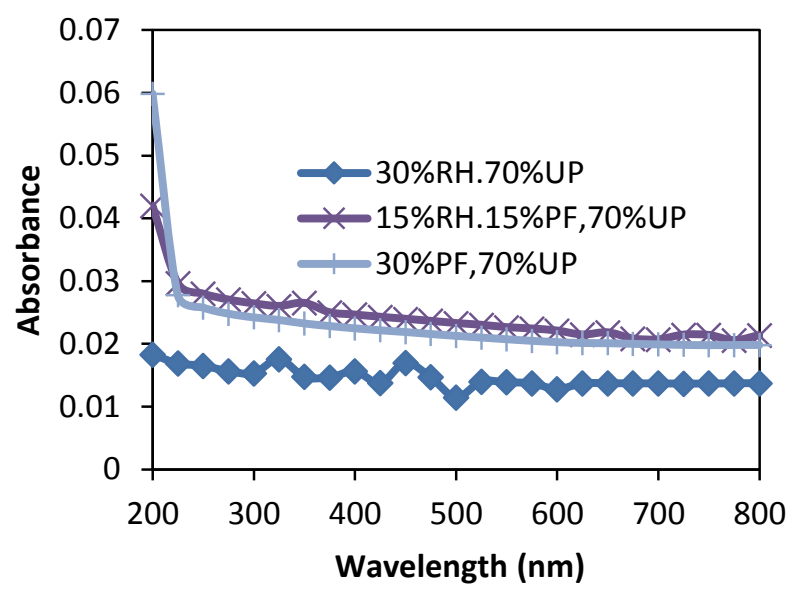

\section{Fig. (3): Absorption spectra of polymer composite samples.}

As shown in Fig.(3) the absorbance tends to decrease with the increasing of wavelength for all types of prepared composite materials, and the best value of absorbance was for $30 \% \mathrm{PF}$, $70 \%$ UP so we can notice that the absorbance increase with the increasing of palm fiber volume fraction, such a change of the light absorbance may be caused by the structural change in the composite. Quantity of impurities and the lowest absorbance is in the visible and IR region. While the highest absorbance shifted to a lower wavelength at higher impurities quantity [15].

It is clear from Fig. (4) that the transmission intensity increases with the increasing of wavelength for all three types of prepared composite materials and it decreases with the increasing of palm fibers ratio because the transmittance represent an inverse relationship with absorbance so the highest absorption corresponds to less transmission [20], the best transmittance was for $30 \% \mathrm{RH}, 70 \% \mathrm{UP}$. 


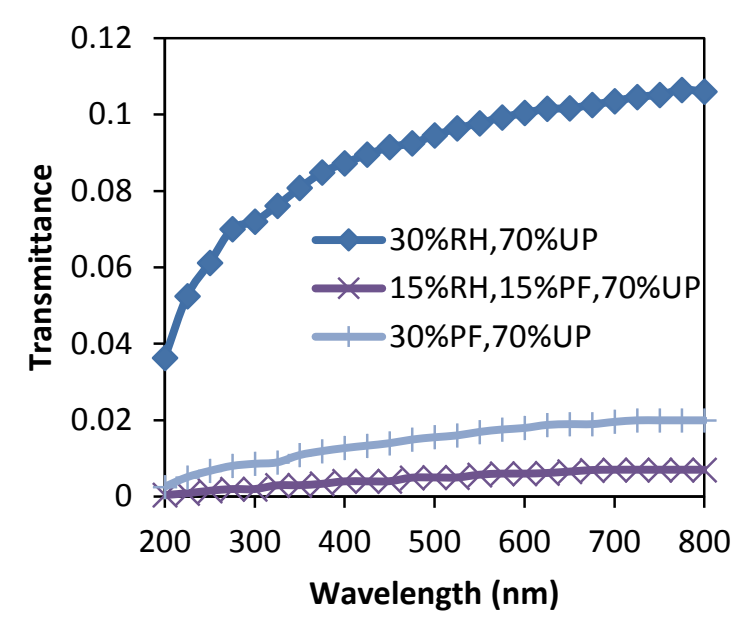

Fig.(4): Transmission spectra of polymer composite samples.

Fig.(5). illustrates the reflectance in the wavelength range (200-800) for the prepared composite materials, one can notice from this figure that the reflectance increases slightly with the increasing of wavelength for $15 \%$ RH, $15 \%$ PF, $70 \%$ UP and 30\% PF, 70\% UP but it decreases for $30 \% \mathrm{RH}, 70 \%$ UP with the increasing of wavelength and the best values of reflectance was for (hybird composite) (15\% RH, 15\% PF, 70\% UP) cause as shown in equation no.(2) the values of the Reflectance depend on the values of both absorbance and transmittance.

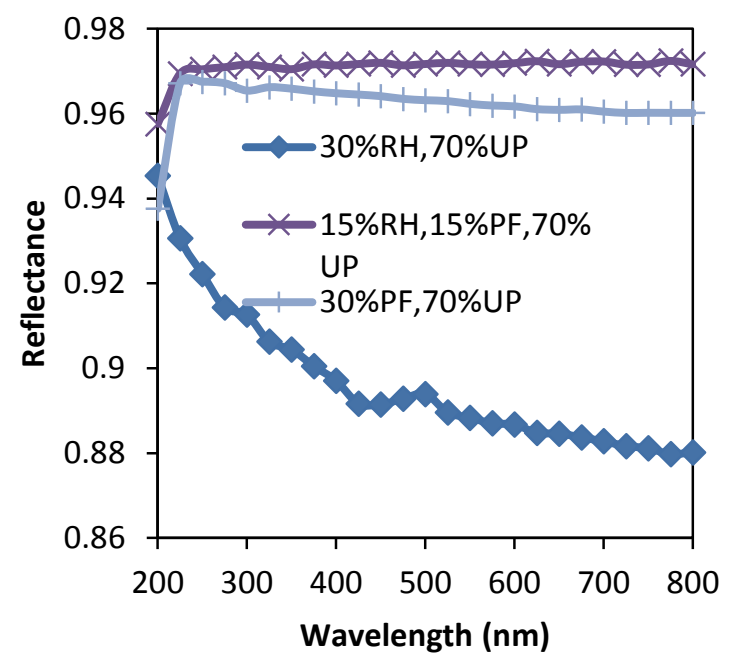

Fig.(5): Reflectance spectra of polymer composite samples.

\section{Extinction coefficient}

The extinction coefficient can be obtained from the relation [16]:

$\mathrm{k}=\alpha \lambda / 4 \pi$
Where $(\alpha)$ is the absorption coefficient and $(\lambda)$ is the wavelength

Fig.(6) Shows the variation of extinction coefficient with the wavelength, the values of extinction coefficient increase with the increasing of wavelength for all prepared composite samples due to the direct electron transitions because the extinction coefficient depends on the absorbance coefficient as shown in equation no.(5), [17] and the best values were for the samples contain a ratio of Palm Fibers.

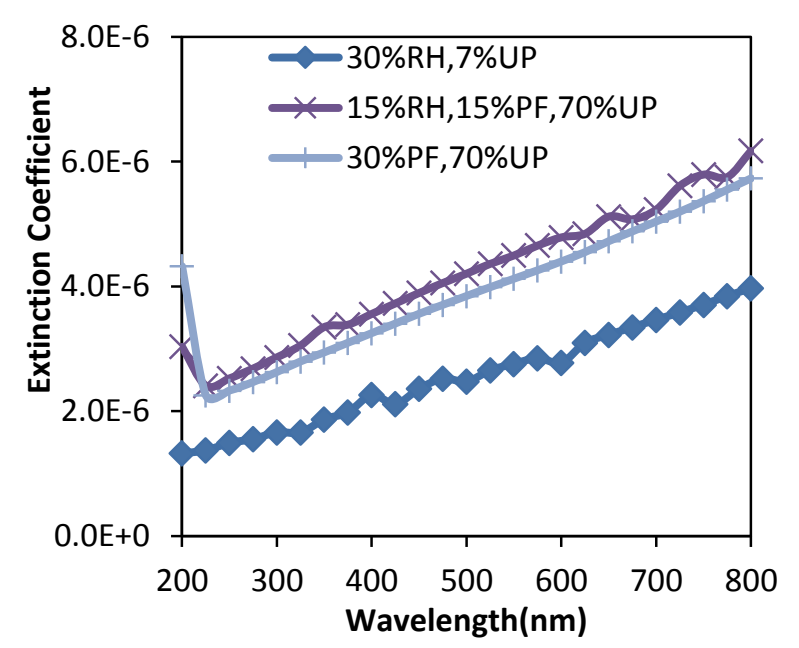

\section{Fig.(6): Extinction coefficient versus} wavelength for three groups.

\section{Refractive Index}

Refractive index is one of the fundamental properties for an optical material because it is closely related to the electronic polarization of ions and the local field inside materials. [7] The refractive index (n) of the prepared polymer composite materials samples can be determined from the absolute values of the reflectance of the prepared polymer composite materials [17]

$\mathrm{n}=\left\{(1+\mathrm{R} / 1-\mathrm{R})^{2}-\left(\mathrm{k}^{2}+1\right)\right\}^{1 / 2}+(1+\mathrm{R}) /(1-\mathrm{R})$.

Fig. (7) represents the dispersion in the refractive index for prepared composite materials in the investigated range of wavelengths. Inspection of the figure indicates that for $30 \% \mathrm{RH}, 70 \%$ UP the refractive index decreases with increasing wavelength but for $15 \% \mathrm{RH}, 15 \% \mathrm{PF}, 70 \% \mathrm{UP}$ and $30 \% \mathrm{PF}, 70 \%$ UP the values of refractive index increase with the increasing of wavelength .we can notice that the values of refractive index (n) are increasing with increase the concentration of 
palm fibers in which attributed to increase the density of composite [15],[21].

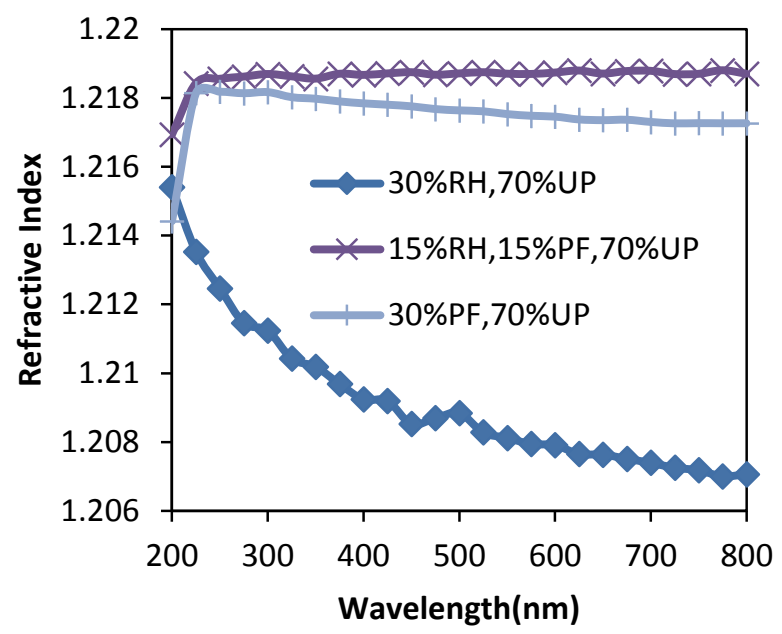

Fig.(7): Refractive Index versus wavelength of three groups.

\section{Determination of the dielectric constant}

The real $\left(\varepsilon_{\mathrm{r}}\right)$ and imaginary $\left(\varepsilon_{\mathrm{i}}\right)$ parts of the dielectric constant were obtained using the formula $\varepsilon_{\mathrm{r}}=\mathrm{n}^{2}-\mathrm{k}^{2}$ and $\varepsilon_{\mathrm{i}}=2 \mathrm{nk}$ [18]. The variation in the real $\left(\varepsilon_{\mathrm{r}}\right)$ and imaginary $\left(\varepsilon_{\mathrm{i}}\right)$ parts of the dielectric constant for different samples are shown in Fig. (8) and (9).

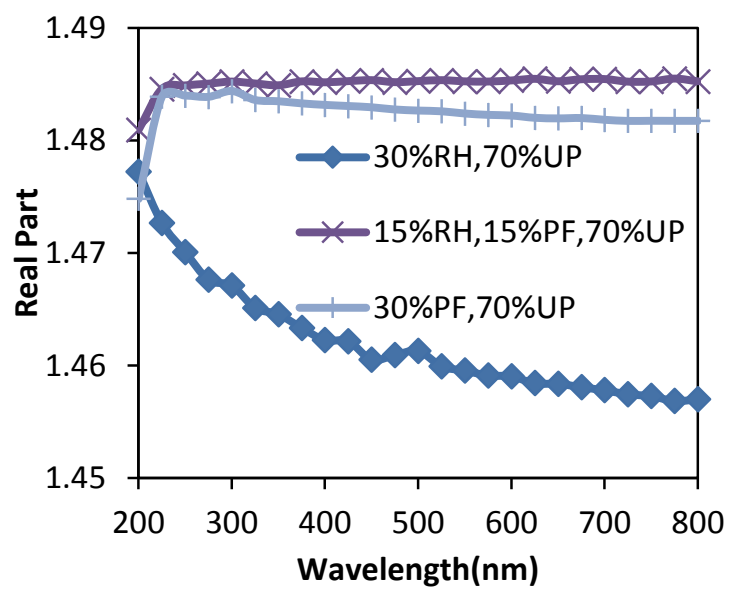

Fig.(8): Real part of dielectric constant versus wavelength of three groups.

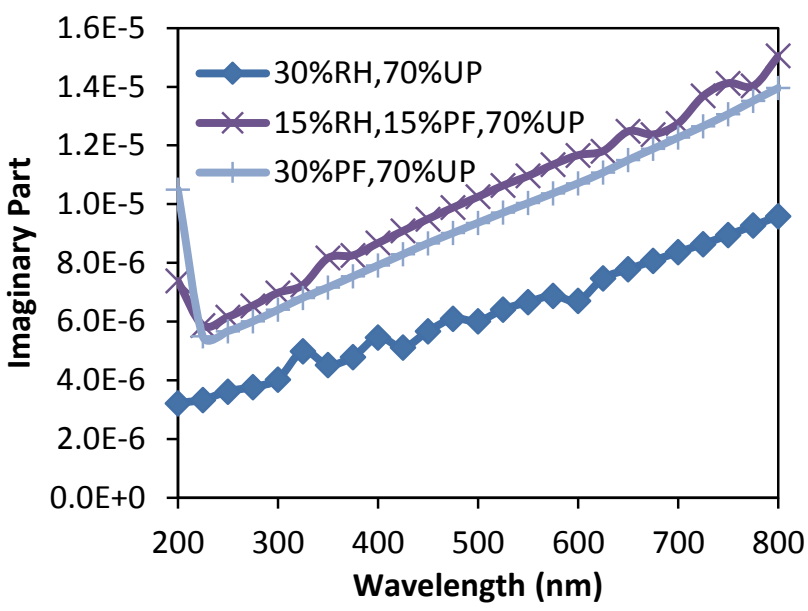

Fig.(9): Imaginary part of dielectric constant versus wavelength of three groups.

It is clear that the variation of $\varepsilon_{\mathrm{r}}$ mainly depends on $\left(\mathrm{n}^{2}\right)$ because of small values of $\left(\mathrm{k}^{2}\right)$, while $\varepsilon_{\mathrm{i}}$ mainly depends on the $(\mathrm{k})$ values which are related to the variation of absorption coefficients. The real part of the dielectric constant is associated with the term that shows how much it will slow down the speed of light in the material and the imaginary part shows how a dielectric absorbs energy from an electric field due to dipole motion [19]. It is clear that the values of real and imaginary parts of dielectric constants were higher in the samples containing ratios of palm fiber than those that contain only rice husks.

The increasing of the concentration of palm fibers attributed to increase the density of composites and number of carries charges[22].

\section{Conclusions}

Through the current study we can conclude the following:

- The absorbance decreases with the increasing of wavelength for all types of prepared composite materials, but the values of absorbance increase with the increasing of palm fiber volume fraction while the transmittance increases with the increasing of wavelength and decreases with increasing of palm fiber ratio.

- The best values of reflectance were for hybrid composite (15\% PF, 15\% RH).

- The values of each Extinction coefficient, Refractive index, real and imaginary parts of dielectric constants were higher in the samples containing ratios of palm fiber than those that contain rice husks only. 


\section{References}

[1] Osama Bedran Hammod; "Thickness Effect on the Optical Properties of PVCMethyldopa Composite Films", Journal of Al-Nahrain University.16 (3),.79-82, September 2013.

[2] Siddika Salma, Mansura Fayecka, and Hasan Mahbub, "Physico-Mechanical Properties of Jute-Coir Fiber Reinforced Hybrid Polypropylene Composites", World Academy of Science, Engineering and Technology 73, 1145-1149, 2013.

[3] Hardinnawirda K. and Siti Rabiatull Aisha I. "Effect of Rice Husks as Filler in Polymer Matrix Composites" Journal of Mechanical Engineering an Sciences, 2,181-186, June, 2012.

[4] Chadramohan D., Marimuthu k. "Tensile and Hardness Tests on Natural Fiber Reinforced Polymer Composite Material", International Journal of advanced engineering science and technologies, 6, 97-104, 2011.

[5] Bongarde U.S., Shinde V.D. "Review on natural fiber reinforcement polymer composites" International Journal of Engineering Science and Innovative Technology (IJESIT) 3(2), 431-436, March 2014.

[6] Drzal Lawrence T., Mohanty A. K., Misra M. "Bio-composite materials as alternatives to petroleum-based composites for automotive applications." Composite Materials and Structures Center, Michigan State University, East Lansing, MI 48824, 2001.

[7] Tagreed K.H. "Refractive Index Dispersion and Analysis of the Optical Parameters of (PMMA/PVA) Thin Film" Journal of AlNahrain University, Science, 16 (3), 164170, 2013.

[8] Wasan A. Musa, Tagreed K. Hamad and Mohammed T. Abdul Nabi "Thickness Effect on the Optical Constants of Poly Methyl Methacrylate (PMMA) Doped by Potassium Iodide, Journal of Al-Nahrain University, Science, 16 (3), 119-123, 2013.

[9] Dana A. Tahir "Optical properties of polymer composite PS-PC thin films" Journal of Kirkuk University-Scientific Studies, 5(2), 93-103, 2010.
[10] Hiba J. Jaafer "Effects of Fibers on Damping Behaviors OF Composites Materials" M.Sc. thesis, department of applied Science, University of Technology, 2010.

[11] Douglas A., Skoog F., James H.S.R., "Principles of Instrumental Analysis"; Thomson Brooks/ Cole, 336, 2007.

[12] Shujahadeen B. Aziz, Sarkawt Hussein, Ahang M. Hussein, and Salah R. Saeed, "Optical Characteristics of Polystyrene Based Solid Polymer Composites: Effect of Metallic Copper Powder", International Journal of Metals Article ID 123657, 2013.

[13] Alias A. N., Zabidi Z. M., Ali A.M.M., Harun M. K., "Optical Characterization and Properties of Polymeric Materials for Optoelectronic and Photonic Applications", International Journal of Applied Science and Technology 3 (5); May 2013.

[14] Nahida, J. H.; Marwa, R.F.; "Study of the Optical Constants of the PMMA/PC Blends"; Eng and Tech. Journal. 29(4), 2011.

[15] Ahmed Hashim, Mohsin K. AlKhaykanee and Ayad Mohammad, "Characterization of (PMMA-CoCl2) Composites" Journal of Babylon University/ Pure and Applied Sciences 21 (7), 2013

$$
\begin{aligned}
& \text { [16] صبري جاسم محمد، خالد حمدي رزيج ومحمد شياع }
\end{aligned}
$$

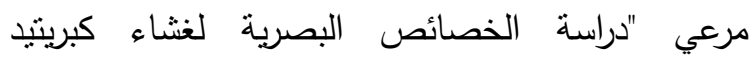

$$
\begin{aligned}
& \text { الكادميوم الرقيق، مجلة سرمن رأى المجلد ب (V) أبلول } \\
& . r . V \\
& \text { [17] وسن كامل حسن "دراسة الخصائص البصرية لمادة } \\
& \text { البولي ستايرين المتراكب" مجلة جامعة كربلاء العلمية، }
\end{aligned}
$$

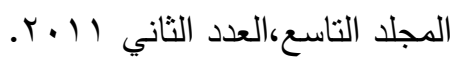

[18] Nadia A. Ali "The Effect of Additive Nano Tube on Optical Properties of Epoxy resin" Iraqi Journal of Physics, 10(19),1-8, 2012.

[19] Tintu R., Saurav K., Sulakshna K., Nampoori V. P. N., Radhakrishnan P., THOMAS S. "Ge28Se60Sb12/PVA Composite Films for Photonic Applications" Journal of Non-Oxide Glasses 2(4), 167- 174, 2010. 
[20] خالد رشيد الراوي، منى مهدي صالح، هند فاضل

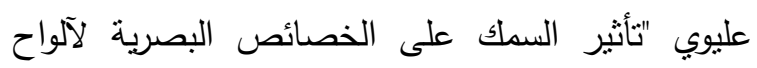

راتتج الاييوكسي النقي" مجلة بغداد للعلوم، 11 (Y)

$. r \cdot 1 \leqslant$

[21] Bahaa H. Rabee, Ahmed Hashim Rawaa Mizher" Preparation of (PVA-AlCl3.6H2O) Composites and Study Optical Properties" American Journal of Scientific Research, 71, 5-8, 2012.

[22] Ahmed Hashim, Majeed Ali Habeeb, Ghaidaa Abdul Hafidh, Ayad Mohammad, Angham. G.Hadi, Hussein Hakim "Study of the Effect of Berry Paper Mulberry on Optical Properties of Poly Methyl Methacrylate", Baghdad Science Journal. 11 (2) 2014.

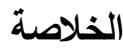

تم في هذا البحث تحضير ثناث مجاميع من المواد

المتراكبة بطريقة الصب وبسمك (0, ·) سم لجميع العينات

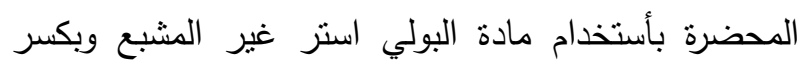
حجمي • \% (الكسر الحجي للبولي استر غير المشبع ثابت في كافة العينات المحضرة) وتدعيمها بقشور الرز وبكسر لإنير

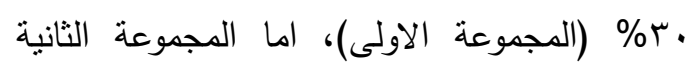

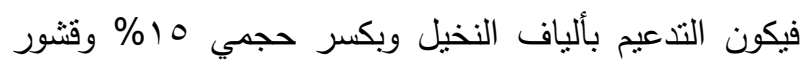
الرز وبكسر حجمي 10\% أيضاً (مركب هجيني) و ونكير المجموعة الثالثة كانت مدعمة بألياف النخيل بكسر حجمي هابري

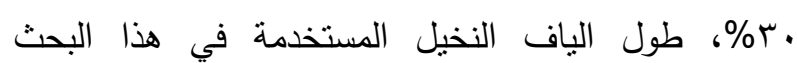

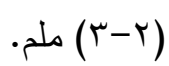

درست الخواص البصرية من خلال قياس الامتصاصية،

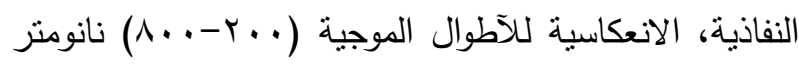

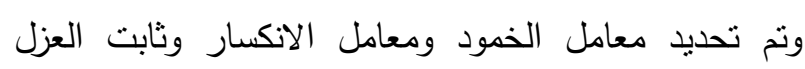

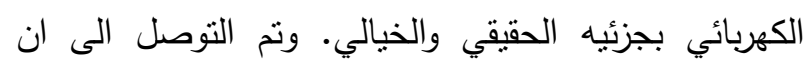
الامتصاصية نزداد بزيادة الكسر الحجمي لألياف النخيل على ولى

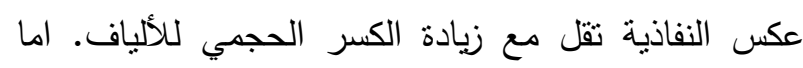
(المتراكب الهجيني) فقد سجل أفضل القيم في الاتعكاسية. ان قيم كل من معامل الخمود معامل الانكسار وثابت العزل بجزئيه الحقيقي والخيالي كانت اعلى في العينات التي تحنوي
على نسب من ألياف النخيل من تللك التي تحتوي على قثور الرز فقط. 